\title{
Italian Society of Neurology
}

\section{Italo-Swiss Meeting}

The third joint meeting of the Italian Society of Neurology and the Swiss Society of Neurology was held at Sion on 6 and 7 June 1980. The joint meeting was inaugurated with an introductory address by Monsieur B. Comby, Conseiller d'Etat du Valais and Chef du Département de la Santé Publique.

22 short papers were presented, 9 of which by Italian authors. As there was no set theme, the topics dealt with covered a wide range: from CSF diagnosis of MS to methods of studying oculomotor changes, from neurosurgical topics to problems of neuropsychology. The papers will be published in the form of Abstracts by the Swiss Archives of Neurology.

At least a hundred Swiss and Italian participants attended the scientific sessions. Traditional Swiss hospitality exceeded all expectations, affording unforgettable opportunities for participants to get to know one another and form friendships.

\section{Italian League against Parkinson's Disease and Extrapyramidal Diseases}

The seventh meeting of the Italian League against Parkinson's Disease and Extrapyramidal Diseases will be held in Milan on 24 and 25 October 1980. The venue will be the Museo Nazionale della Scienza e della Tecnica, Via San Vittore 21.

The themes of the meeting will be: Dystonias and Dyskinesias and ten years of therapy with Levodopa + inhibitors.

The first day will be devoted to the presentation of papers and the second day to the discussion by a panel of invited speakers on "Ten years of therapy with Levodopa + inhibitors". T.N. Chase (Bethesda) will attend the meeting as an invited speaker.

Prof. Lodovico Frattola (Clinica Neurologica dell'Università di Milano, Ospedale Bassini, Via M. Gorki, Cinisello Balsamo, Milano, tel. 02/61.75.541) and Prof. Tommaso Caraceni (Istituto Neurologico C. Besta, Via Celoria 11, Milano, tel. 02/236.24.51) will look after the local organisation. 